\title{
A new case of primary signet-ring cell carcinoma of the cervix with prominent endometrial and myometrial involvement: Immunohistochemical and molecular studies and review of the literature
}

\author{
Giovanna Giordano ${ }^{1 *}$, Silvia Pizzi ${ }^{1}$, Roberto Berretta ${ }^{2}$ and Tiziana D'Adda ${ }^{1}$
}

\begin{abstract}
Background: As a rule, endocervical tumours with signet-ring cell are classed as metastatic extra-genital neoplasms. In a patient aged 45 years, we describe primary cervical signet-ring cell carcinoma (PCSRCC) characterized by prominent endometrial and myometrial involvement, simulating primary endometrial adenocarcinoma with cervical extension. In addition, a review was made of the literature to identify the clinical and pathological features of this rare malignancy.

Case presentation: A 45-year-old woman was referred to our Gynaecology Department due to persistent abnormal vaginal bleeding. Transvaginal ultrasonography showed slight endometrial irregularities in the whole uterine cavity suggestive of endometrial neoplasms. Pelvic magnetic resonance imaging revealed diffuse enlargement of the cervix, which had been replaced by a mass. Induration extended to the parametria and sigmoid colon fat.

Histological examination of endometrial curettage and a cervical biopsy revealed a neoplasm characterized by neoplastic signet-ring cells and trabecular structures. Immunohistochemical analysis and molecular studies showed certain findings consistent with a cervical neoplasm, such as positivity to CEA, keratin 7, Ca-125 and p16 and the presence of HPV (Human Papilloma Virus) DNA 18.

On examination of the hysterectomy with bilateral salpingo-oophorectomy and pelvic lymphadenectomy, the lesion replacing the cervix, endometrium and myometrium, revealed the same immunohistochemical findings observed on endometrial curettage and cervical biopsy specimens. Metastases were found in an ovarian cystic lesion and the lymph nodes.
\end{abstract}

Conclusion: With this report the authors have demonstrated that the spread of cervical adenocarcinoma to the uterine corpus, although rare, may be observed, and that in this instance immunohistochemical and molecular studies can provide sufficient information for accurate diagnosis even on small biopsy specimens.

Keywords: Signet-ring cell carcinoma, Cervical adenocarcinoma, Human Papilloma Virus (HPV), Polymerase Chain Reaction Amplification (PCR)

\footnotetext{
* Correspondence: giovanna.giordano@unipr.it

'Department of Pathology and Medicine of Laboratory, Section of Pathology,

Parma University

Full list of author information is available at the end of the article
} 


\section{Background}

Signet-ring cell carcinoma is an epithelial malignancy characterized by the presence of cells with a signet-ring appearance. This appearance is due to a large vacuole full of mucin displacing the nucleus to the periphery. Thus, the pool of mucin in a signet-ring cell mimics the appearance of a finger hole, while the nucleus represents the face of the ring in profile [1]. Signet-ring cell carcinoma is considered a form of adenocarcinoma [1].

Signet-ring cells are most frequently associated with stomach cancer [1], but may be observed in any tissue including the prostate [2] bladder, gallbladder [3] breast, and colon [4] as well as in stromal tumours of the ovary and testis [5].

Most signet-ring cell carcinomas in the female genital tract are extra-genital metastatic neoplasms [3,6-9].

Primary signet-ring carcinomas of the female genital organs, on the other hand, may be considered a rare event. In fact, primary signet-ring cell carcinoma of the endometrium has only been observed in 4 previous cases [10-12].

Moreover, to the best of our knowledge, no more than 14 cases of primary cervical carcinoma containing signet-ring cells have been reported in the English literature [13-22].

In this paper, we report a new case of primary signetring cell carcinoma of the cervix (PSRCC) with prominent endometrial and myometrial involvement simulating endometrial adenocarcinoma with extension to the cervix or metastatic extra-genital tumour (OK). The results of immunohistochemical and molecular studies have been reported as ancillary techniques to provide information for a more accurate diagnosis of this rare malignancy. In addition, we reviewed the literature to identify the clinical and pathological features of this rare malignancy.

\section{Case presentation}

The materials consisted of cervical and endometrial biopsy specimens, plus specimens from hysterectomy with bilateral salpingo-oophorectomy and pelvic lymphadenectomy. The specimens were fixed in $10 \%$ neutral-buffered formalin for a routine light microscope examination. The samples were embedded in paraffin, then $3 \mu$ sections were cut and stained with haematoxylin-eosin. Immunohistochemistry was performed with antibodies anti-Ca 125 (Dilution 1:100, clone: M11, Dako, Glostrup, Denmark), CEA (Dilution 1:200, clone: 11-7, Dako, Glostrup, Denmark), anti keratin 7 (Dilution:1:200, clone OV-TL 12/30, Neomarkers, PleasaltonCA), and p16 ${ }^{\mathrm{INK} 4 \mathrm{a}}$ (Kit Cinetec p16 ${ }^{\text {INK4a }}$, Heidelberg, Germany), Vimentin (Neomarkers, dilution:1:500, clone: V9, Neomarkers, Pleasalton-CA), anti-oestrogen receptors (Dilution:1:50, clone: SP1, Neomarkers, Pleasalton-
CA), anti-progesterone receptors, (Dilution:1:200, clone: P8R636, Dako, Glostrup, Denmark), Chromogranin A (Dilution:1:2000, clone: LK 2H10+ PHE5, Neomarkers, Fremont-CA) and Synaptophysin (Dilution:1:100, polyclonal, Cell Marque, Hot Springs, AR, USA), using the avidin-biotin method.

Polymerase chain reaction amplification (PCR) was performed to evaluate the presence of HPV DNA in the cervical and endomyometrial neoplasm.

For DNA extraction, $4 \mu \mathrm{m}$-thick histological sections were stained with haematoxylin and examined under a stereomicroscope. Neoplastic areas were manually micro-dissected using sterile scalpels, suspended in a buffer for tissue lysis (Tris $\mathrm{HCl} 50 \mathrm{mM}, \mathrm{pH} 9,1 \mathrm{mM}$ EDTA pH 8.0, 0.5\% Tween 20, 5\% Chelex 100), and incubated overnight with Proteinase $\mathrm{K}(0.4 \mathrm{mg} / \mathrm{ml})$ at $55^{\circ} \mathrm{C}$. After enzyme inactivation by $10 \mathrm{~min}$ boiling, DNA extracted was used directly in the PCR mix, without further purification.

HPV-PCR amplification was performed with L1 consensus primers Gp5+/Gp6+ [23], giving an expected PCR product size of $150 \mathrm{bp}$ : these primers, which were distinct but pooled, have been developed to allow the detection of a broad spectrum of mucosotropic HPV genotypes $(6,11,13,16,18,30-35,39,40,42,45,51-53$, $56,58,61,66)$. Most of these genotypes are correlated with lesions of high oncogenic risk (16,18,45,56 and 58). Five $\mu \mathrm{l}$ of appropriately diluted DNA were combined in a $25 \mu \mathrm{l}$ reaction mixture containing $10 \mathrm{mM}$ Tris $-\mathrm{HCl}$ (pH 9.0), $50 \mathrm{mM} \mathrm{KCl}, 0.1 \%$ Triton X-100, $200 \mu \mathrm{M}$ of each dNTP (Promega, Madison, WI, USA), $0.4 \mu \mathrm{M}$ of each primer, $2.0 \mathrm{mM} \mathrm{MgCl} 2,1.25 \mathrm{U}$ Taq polymerase (Promega, Madison, WI, USA). Amplification was carried out for 40 cycles in an AB 2700 (Applied Biosystems, Foster City, CA, USA) thermal cycler. Each cycle of amplification consisted of 1 min denaturation at $94^{\circ}$ C, 1 min annealing at $46^{\circ} \mathrm{C}$, and $1 \mathrm{~min}$ of elongation at $72^{\circ} \mathrm{C}$. The first cycle was preceded by $7 \mathrm{~min}$ denaturation at $94^{\circ} \mathrm{C}$ while the last cycle was followed by a 7 min elongation step at $72^{\circ} \mathrm{C}$. PCR for human $\beta$-globin gene was performed to establish the presence of amplifiable DNA and to exclude the presence of inhibitory factors of the PCR reaction [24]. Sequencing of the GP5 +/GP6+ amplimer was performed as follows. PCR reaction was slightly modified, using $1 \mathrm{pM}$ of each primer, $1.5 \mathrm{mM} \mathrm{MgCl} 2$ and 1.25 units of AmpliTaq Gold (Applied Biosystem, Foster City, CA). Amplification conditions were as previously indicated. PCR products were purified using the NucleoSpin ${ }^{\circledR}$ Extract II kit (Macherey-Nagel, Düren-Germany) according to manufacturer's instruction. DNA sequencing was performed by Eurofins MWG Operon/M-Medical (Milano, IT). Sequencing results were verified in our laboratory in both sense and anti-sense directions using DNA STAR 
PC software (Lasergene, Madison, WI USA). HPV type was determined using the BLAST (Basic Local Alignment Search Tool) Search function of the Papilloma Virus Episteme (PaVE) Database (http://pave.niaid.nih. gov).

The patient was a 45 -year-old woman who had been referred to our Gynaecology Department because of persistent abnormal vaginal bleeding. Gynaecological examination revealed diffuse enlargement of the cervix which had been replaced by an exophytic ulcerated, reddish lesion. Transvaginal ultrasonography showed slight endometrial irregularities in the whole uterine cavity suggestive of endometrial neoplasms. Pelvic magnetic resonance imaging revealed diffuse enlargement of the cervix which had been replaced by a mass. Induration extended to the parametria and sigmoid colon fat. (Preoperative FIGO stage: IIB).

Endometrial curettage and cervical biopsy were performed. On histological examination, both specimens revealed the presence of a neoplasm characterized by neoplastic signet-ring cells and trabecular structures (Figure 1).

Periodic acid Schiff (PAS) and blue alcian stains revealed the presence of intracellular mucin in the signet-ring cells.

Immunohistochemical analysis showed findings consistent with a primary cervical neoplasm, including positivity to keratin 7, Ca-125, CEA, and p16 and negativity to Vimentin in both endometrial (Figure 2) and cervical biopsy (Figure 3), oestrogen and progesterone receptors. The cervical origin of the neoplasm was also supported by the presence of HPV DNA (Figure 4) by Polymerase chain reaction amplification (PCR) and sequencing analysis which demonstrated the presence of HPV 18 (Figure 5).

The cervical origin of the neoplasm was further demonstrated by the absence of other neoplasms on oral endoscopy, thorax, abdominopelvic computed tomography, colonoscopy and mammography study.

The absence of immunoreactivity to Chromogranin $A$ and synaptophysin excluded neuro-endocrine differentiation.

A total abdominal hysterectomy, bilateral salpingooophorectomy, and selective pelvic lymphadenectomy, omentectomy and resection of sigmoid colon were performed.

Macroscopic examination of the hysterectomy specimen revealed an ulcerated cervical mass and irregularities in the whole endometrial cavity. On cut section, white neoplastic tissue extended through the entire myometrial wall thickness to involve the uterine serosa. Examination of bilateral salpingo-oophorectomy specimens revealed a right ovarian cystic lesion with multiple white nodules on its surface. White neoplastic nodules were also observed in the sigmoid colon fat.

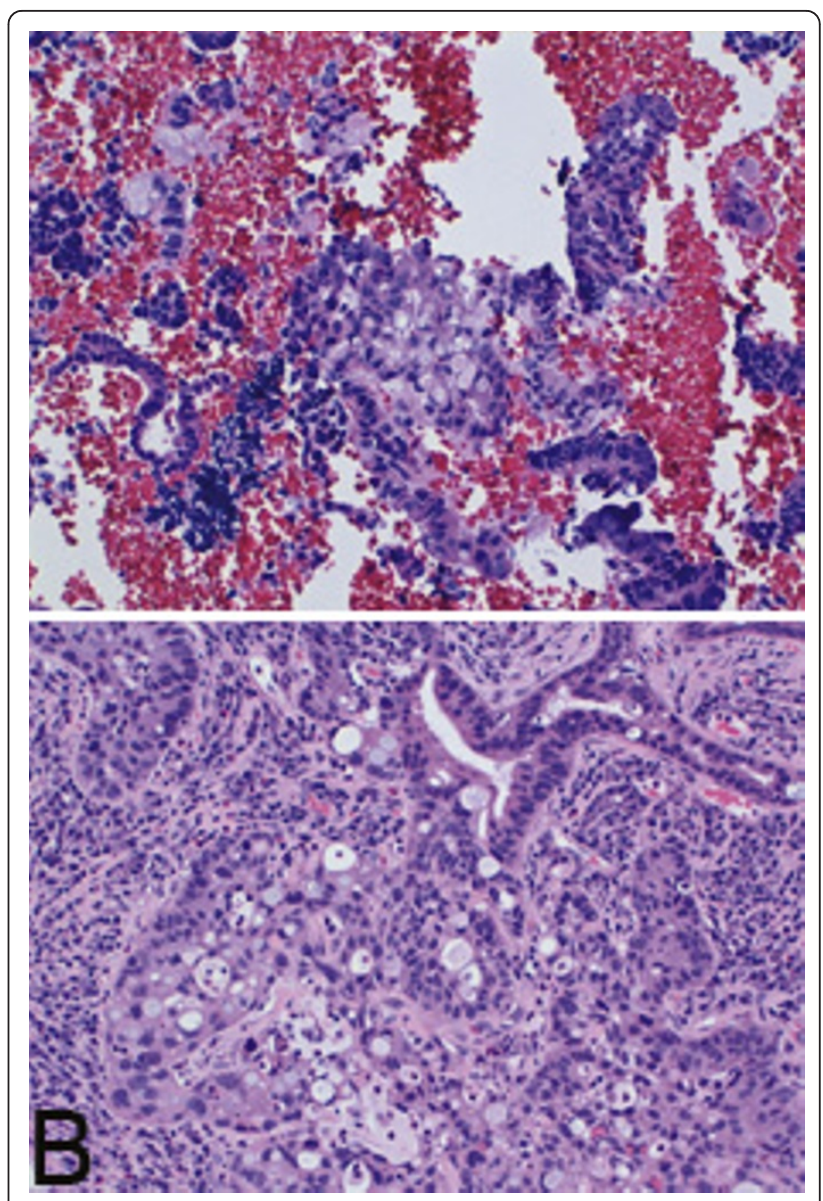

Figure 1 On histological examination both endometrial curettage (A: Haematoxylin-Eosin $\times 100$ ) and cervical biopsy (B: Haematoxylin-Eosin $\times 200$ ) specimens revealed the presence of a neoplasm characterized by neoplastic signet-ring cells and trabecular structures.

Microscopic evaluation confirmed the initial diagnosis of primary cervical adenocarcinoma with signet-ring elements and prominent endometrial and myometrial involvement.

Characteristically, the entire endometrial mucosa and myometrial wall thickness were involved. The endometrial component consisted of trabecular and glandular structures and signet-ring elements which accounted for $30 \%$ of the tumour (Figure $6 \mathrm{~A}$ ). In the myometrial part, the tumour was characterized by lakes of mucus in which neoplastic elements were floating (Figure 6B). All the nodules observed in the sigmoid colon fat and the cystic lesion of the right ovary were metastases of the cervical neoplasm, while other metastases were observed in 3 pelvic lymph nodes.

\section{Discussion}

It is universally recognized that adenocarcinomas which accumulate mucin in large single or aggregated 


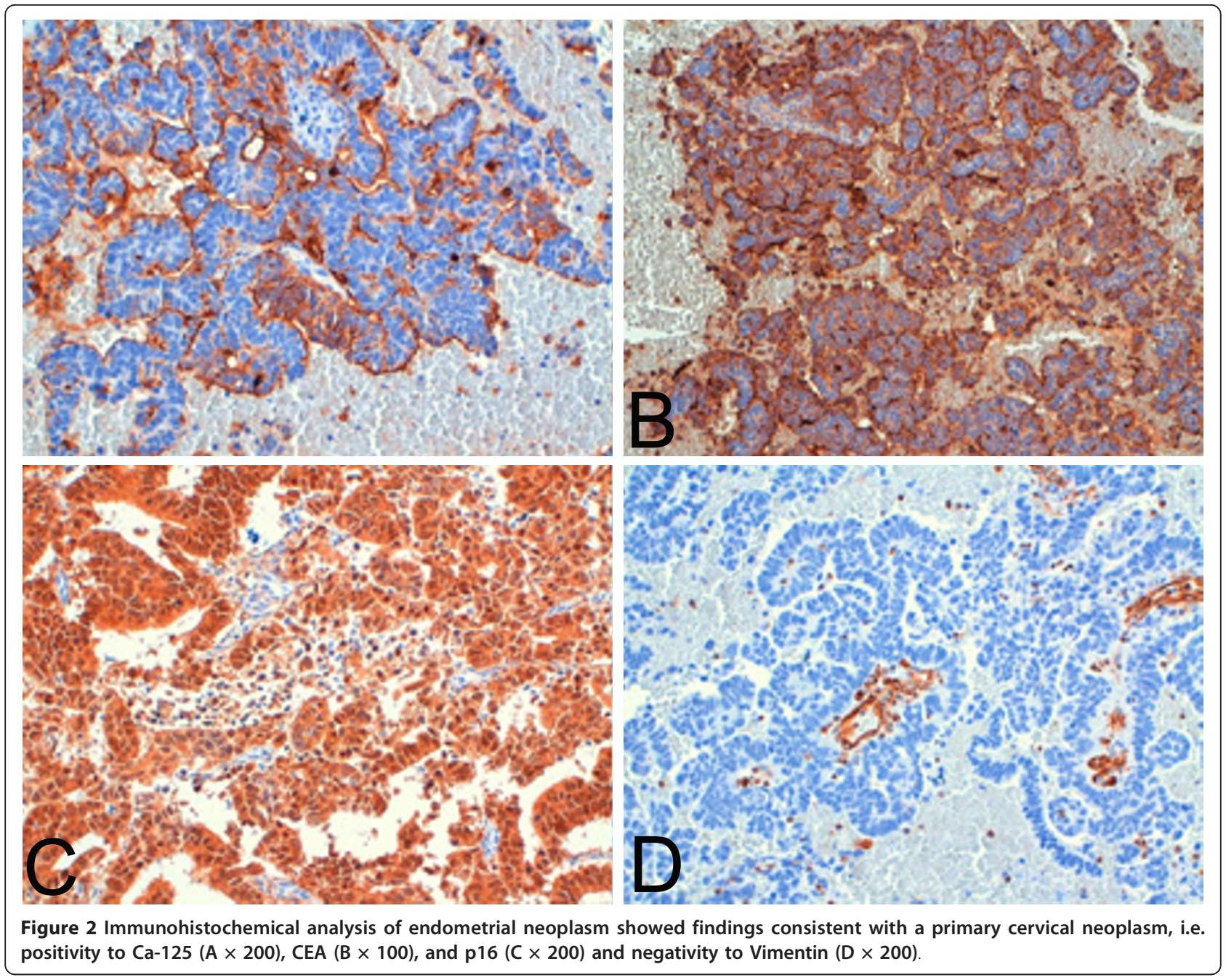

intracytoplasmic vacuoles displacing the nucleus peripherally, correspond to signet-ring cell carcinoma.

In certain tissues these malignancies are generally characterized by poor prognosis $[25,26]$.

Several researchers have reported artifactual vacuoles and non-adenocarcinomatous neoplasms in various organs and tissues, including the prostate, lymphomas and the ovaries [27-30].

Non-neoplastic endometrial stromal signet-ring cells may be observed during decidualization, when endometrial stromal cells acquire cytoplasmic vacuoles secondary to the accumulation of glycogen and glycoproteins $[31,32]$. A lack of staining for mucin as well as immunohistochemical non-reactivity for epithelial markers typically allows recognition of these non-neoplastic elements.

The presence of signet-ring cells in a carcinoma within the cervix or in other organs of the genital tract strongly suggests the possibility of a metastasis from a primary tumour of the breast or gastrointestinal tract
[3,6-9]. Immunohistochemical and molecular studies have provided information for differential diagnosis in some instances. Monteagudo et al observed that in the majority of cases, the signet-ring variant of breast cancer metastatic to the ovary showed positivity to gross cystic disease fluid protein -15 (GCDFP-15) [33]. In contrast, immunoreactivity to colorectal antigens such as CEA, CDX-2 (20) and CK 20 [19] in a cervical lesion does not rule out a diagnosis of primary cervical carcinoma.

As well as cervical cases, adenocarcinomas express markers common to gastric, intestinal and pancreatobiliary epithelial cells [34]. Moreover, simultaneous positivity to CEA and keratin 7 do not differentiate between PCSRCC and mammary metastatic malignancy [35].

To the best of our knowledge, only 14 cases of primary cervical carcinoma containing signet-ring cells have been reported in the English literature [13-22] (Table 1).

The majority of the patients in these reports are postmenopausal women $[13,14,16,19,22]$. Conspicuous 


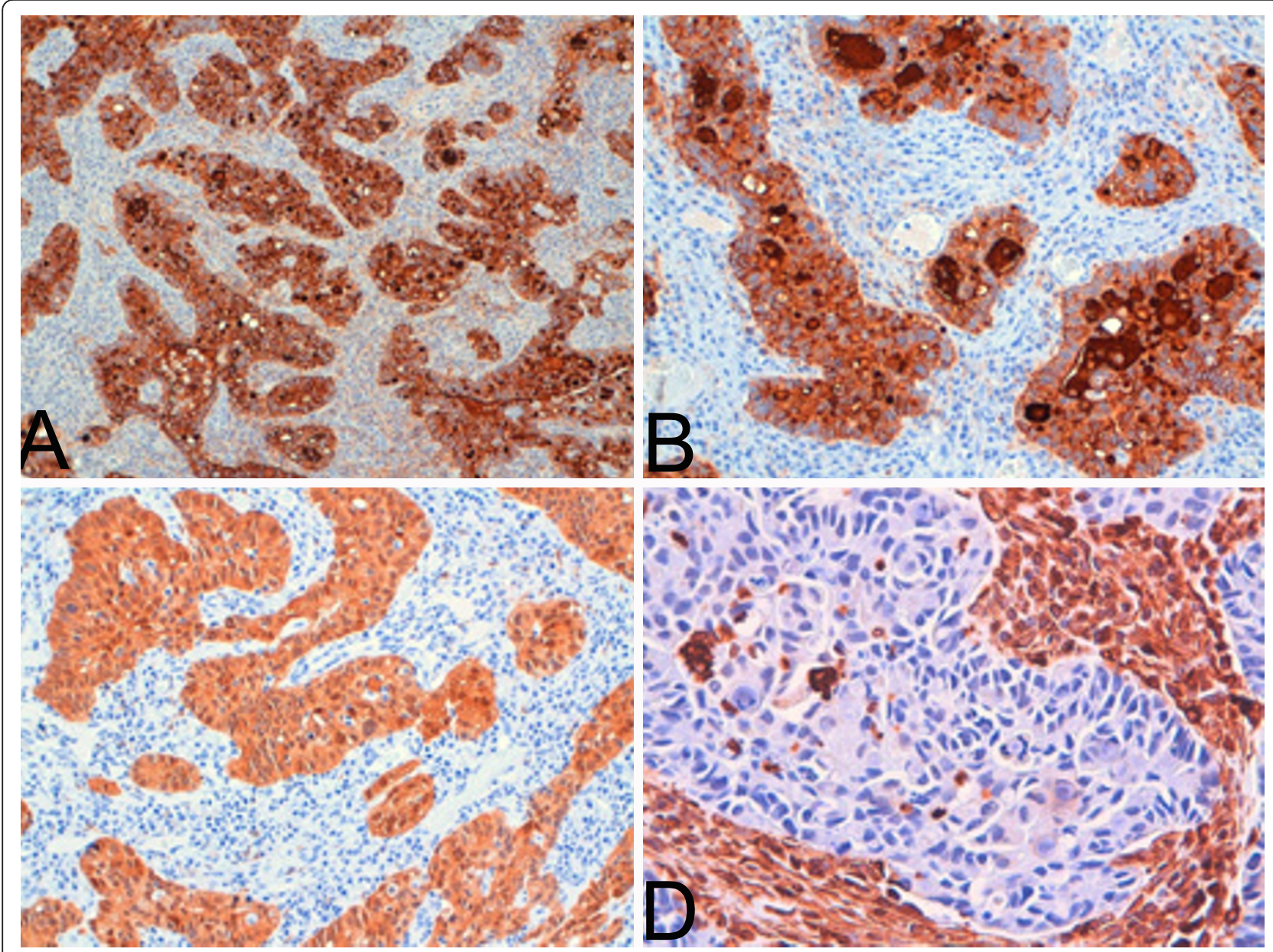

Figure 3 Immunohistochemical analysis of cervical neoplasm showed findings consistent with a primary cervical neoplasm, i.e. positivity to $C a-125(A \times 100)$, CEA $(B \times 200)$, p16 $(C \times 200)$ and negativity to Vimentin $(D \times 400)$

signet-ring cells were reported in 7 cases $[13,15,16$, $18,19,22]$, while concomitant glandular structures $[16,20]$ or tubular and tubuloglandular formations $[13,15]$ have been described in some cases. In the case reported by Insabato et al, the neoplasm was associated with adenocarcinoma in situ (AIS) [18] and in that described by Haswani et al, both AIS and a high-grade squamous intraepithelial lesion were present [15], but these were absent in our case. A simultaneous glassy cell component was observed in a young Japanese

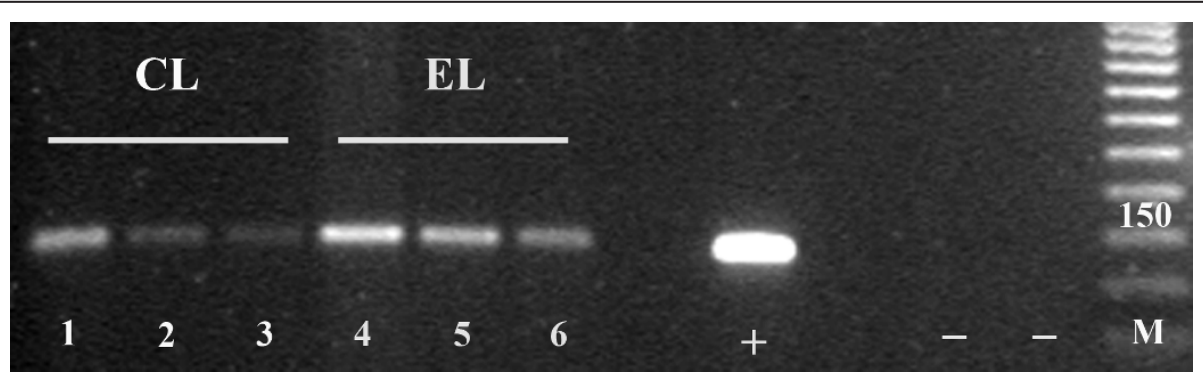

Figure 4 Results of HPV-PCR amplification using the L1 consensus primers Gp5+/Gp6+ showing strong positivity for HPV-DNA in both endometrial and biopsy specimens: Lanes 1, 2, 3: CL (Cervical neoplastic lesion) DNA at three different dilutions, with strong signal for HPV-DNA. Lanes 4: 5, 6: EL (Endometrial neoplastic lesion) DNA at three different dilutions, with strong signal for HPV-DNA. M: molecular weight standard; + = HPV positive control; - = HPV negative control. 


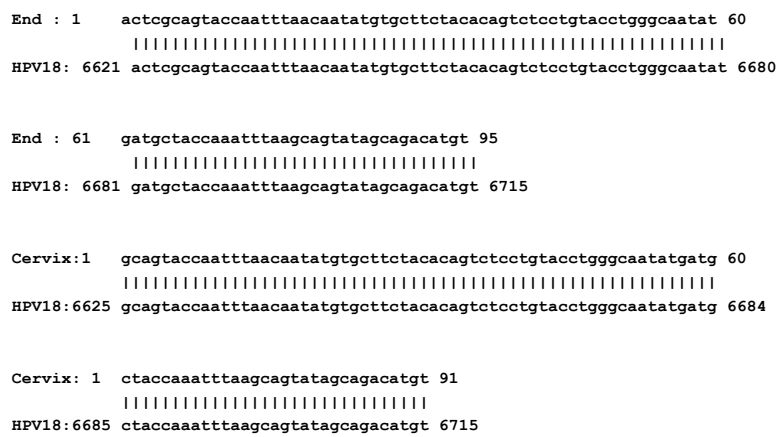

Figure 5 Sequence alignment illustrating 100\% identities between Human papillomavirus type 18 reference sequence (PAVE entry X05015.1) and HPV DNA from both endometrial and cervical specimens. (End: endometrial lesion)

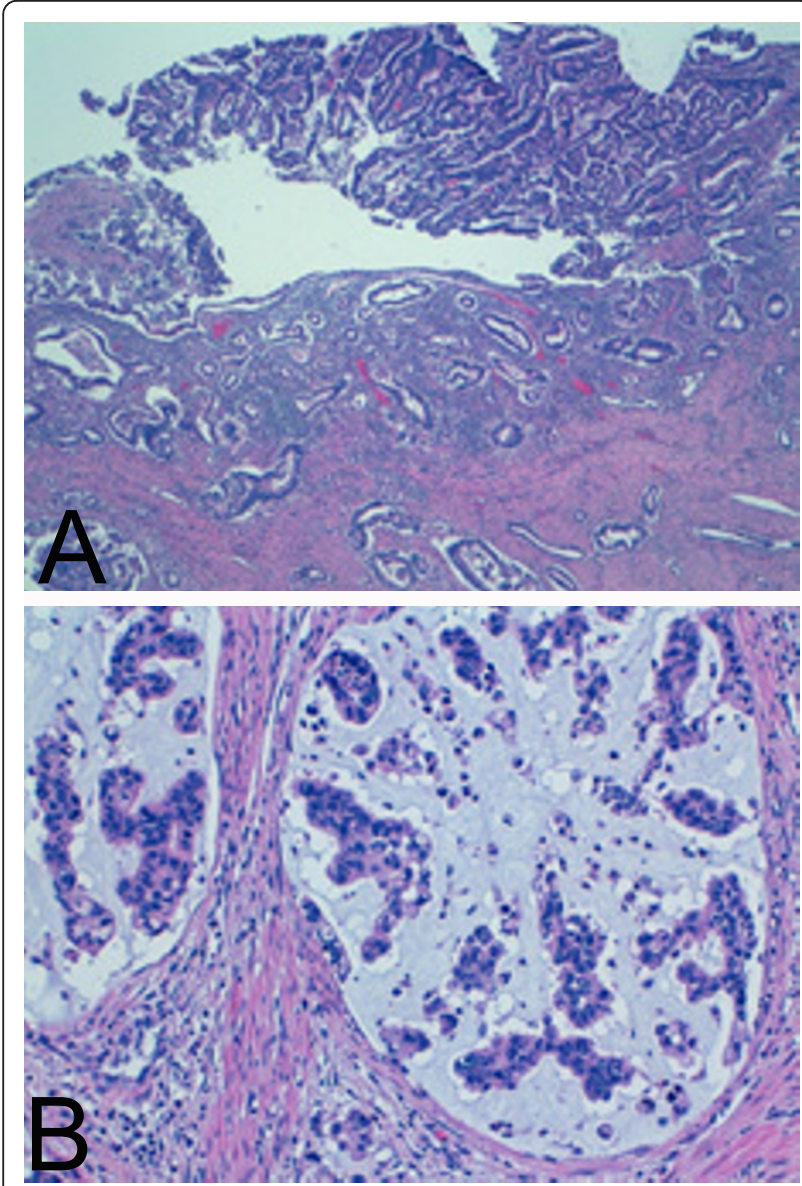

Figure 6 Microscopic examination of hysterectomy specimen revealed the presence of neoplasm with endometrial and myometrial involvement. The endometrial component of the neoplasm was formed by predominant trabecular and glandular structures (A: Haematoxylin-Eosin $\times 40$ ) In the myometrial part, the tumour was characterized by lakes of mucus in which neoplastic elements floated (B: Haematoxylin-Eosin $\times 100$ ). woman by Moritani et al [17], while partial enteric immunophenotype with consistent expression of CDX2 marker has been described by McCluggage et al [20].

Oestrogen and Progesterone receptors have been tested in only 4 previous cases $[15-17,19,21]$ and these were present only in one example [16].

Neuroendocrine differentiation by using neuroendocrine markers such as Chromogranin A [19] and both Chromogranin A and Synatophysin [16] have been demonstrated in two cases, but these markers were negative in our case.

In our case, as well as in some previous published examples of the PCSRCC, the primary cervical origin was supported by the presence of HPV DNA using molecular analysis $[15,22]$ and by P16 immunoreactivity $[20,22]$, which may be considered a surrogate marker for HPV infection [36].

Prognosis for PCSRCC is not well understood because of its rarity [13-22]. Moreover, is not possible to draw convincing conclusions about the prognostic significance of signet-ring component in endocervical carcinoma since the follow-up period in the majority of the previous cases reported in the literature is either too short [15-17] or was not reported [20,22] (Table 1). However, in our opinion, prognosis in this rare malignancy should be considered poor at more advanced stages of the disease.

This hypothesis is supported by data in the literature which show that all patients with an advanced stage of development of neoplasm (stage III sec FIGO) died from the disease after only 10 [13] or 18 months [15,19] and 7 weeks and 2 months from diagnosis [21]. Moreover, in these examples of PRSCC, the authors had also documented that this rare malignancy showed resistance to radiotherapy and/or chemotherapy $[13,15,19,21]$. In cases observed by Veras et al, the PCSRCC were characterized by widespread metastatic disease with systemic thromboembolic phenomena (Trousseau syndrome) and both patients expired shortly after initiation of chemotherapy (Table 1). In these cases, Veras et al excluded metastatic adenocarcinomas of the upper gastrointestinal tract origin because of the presence of HPV DNA by in situ hybridization [21].

In cases with a lower stage of development (stage Ib sec FIGO) prognosis is better. Indeed, in the cases described by Mayorga et al and Insabato et al, the patients showed no evidence of disease several months after diagnosis $[14,18]$.

Generally, cervical carcinoma spreads to the parametria and/or vagina. In our case, the neoplasm had involved the uterine corpus and showed prominent endometrial and myometrial infiltration simulating primary endometrial adenocarcinoma with cervical extension. Data from the literature reveal that the spread of 
Table 1 Previous Reported cases of PCSRCC

\begin{tabular}{|c|c|c|c|c|c|c|c|}
\hline Authors & $\begin{array}{l}\text { Age } \\
\text { (yrs) }\end{array}$ & Presenting symptoms & $\begin{array}{l}\text { Histological features } \\
\text { associated } \\
\text { and } \\
\text { FIGO stage }\end{array}$ & $H P V$ & $\begin{array}{l}E R / \\
P G R\end{array}$ & Treatment & Outcome \\
\hline $\begin{array}{l}\text { Moll et al } \\
\text { (1990) }\end{array}$ & 50 & $\begin{array}{l}\text { Post-coital vaginal bleeding, } \\
\text { menometrorrhagia }\end{array}$ & $\begin{array}{l}\text { III (metastases of ovary and } \\
\text { lymph nodes) }\end{array}$ & Not done & $\begin{array}{l}\text { Not } \\
\text { done }\end{array}$ & $\begin{array}{l}\text { Surgery and } \\
\text { whole pelvic } \\
\text { irradiation }\end{array}$ & $\begin{array}{l}\text { DOD } 10 \\
\text { mo }\end{array}$ \\
\hline $\begin{array}{l}\text { Mayorga et } \\
\text { al (1997) }\end{array}$ & $\begin{array}{l}68 \\
74\end{array}$ & $\begin{array}{l}\text { Post-coital bleeding } \\
\text { Post-menopausal bleeding }\end{array}$ & $\begin{array}{l}\mathrm{lb} \\
\mathrm{lb}\end{array}$ & $\begin{array}{l}\text { Not done } \\
\text { Not done }\end{array}$ & $\begin{array}{l}\text { Not } \\
\text { done } \\
\text { Not } \\
\text { done }\end{array}$ & $\begin{array}{l}\text { Preoperative } \\
\text { chemotherapy } \\
\text { and surgery } \\
\text { Surgery }\end{array}$ & $\begin{array}{l}\text { NED } 35 \\
\text { mo } \\
\text { NED } 25 \\
\text { mo }\end{array}$ \\
\hline $\begin{array}{l}\text { Haswani et } \\
\text { al (1998) }\end{array}$ & $\begin{array}{l}33 \\
38\end{array}$ & $\begin{array}{l}\text { Asymptomatic AGC-NOS on a } \\
\text { routine vaginal smear) } \\
\text { Post-coital vaginal bleeding } \\
\text { In both cases previous cervical } \\
\text { condylomas }\end{array}$ & $\begin{array}{l}\text { Adenosquamous ca, III, N1 } \\
\text { AIS/HSIL } \\
\text { Ib N1 }\end{array}$ & $\begin{array}{l}\text { HPV type } 18 \text { by PCR } \\
\text { Not done }\end{array}$ & $\begin{array}{l}-1 \\
-1\end{array}$ & $\begin{array}{l}\text { Palliative radio } \\
\text { and } \\
\text { chemotherapy } \\
\text { Surgery and } \\
\text { radiotherapy }\end{array}$ & $\begin{array}{l}\text { DOD } 10 \\
\text { mo } \\
\text { NED } 18 \\
\text { mo }\end{array}$ \\
\hline $\begin{array}{l}\text { Cardosi et al. } \\
\text { (1999) }\end{array}$ & 53 & Perimenopausal bleeding & $\begin{array}{l}\text { neuroendocrine } \\
\text { differentiation } \\
\mathrm{lb}\end{array}$ & Not done & $+/+$ & $\begin{array}{l}\text { Surgery, } \\
\text { radiotherapy } \\
\text { Chemotherapy }\end{array}$ & $\begin{array}{l}\text { NED } 6 \\
\text { mo }\end{array}$ \\
\hline $\begin{array}{l}\text { Moritani et al } \\
\text { (2004) }\end{array}$ & 29 & $\begin{array}{l}\text { Persistent abnormal genital } \\
\text { bleeding }\end{array}$ & $\begin{array}{l}\text { glassy cell component } \\
\text { III b N1 }\end{array}$ & $\begin{array}{l}\text { - by } \\
\text { immunohistochemistry }\end{array}$ & $-/-$ & Chemotherapy & $\begin{array}{l}\text { NED } 6 \\
\text { mo }\end{array}$ \\
\hline $\begin{array}{l}\text { Insabato et } \\
\text { al (2007) }\end{array}$ & 46 & $\begin{array}{l}\text { Vaginal bleeding } \\
\text { in cervical polypoid lesion }\end{array}$ & $\mathrm{Ib}$ & Not done & $\begin{array}{l}\text { Not } \\
\text { Done }\end{array}$ & $\begin{array}{l}\text { Surgery } \\
\text { radiotherapy } \\
\text { Chemotherapy }\end{array}$ & $\begin{array}{l}\text { NED } 3 \\
\text { yrs }\end{array}$ \\
\hline $\begin{array}{l}\text { Suárez- } \\
\text { Peñaranda } \\
\text { (2007) } \\
\end{array}$ & 80 & Vaginal discharge & $\begin{array}{l}\text { neuroendocrine } \\
\text { differentiation IIIb }\end{array}$ & Not done & $\begin{array}{l}\text { Not } \\
\text { Done }\end{array}$ & $\begin{array}{l}\text { Radiotherapy/ } \\
\text { Chemotherapy }\end{array}$ & $\begin{array}{l}\text { DOD } 18 \\
\text { mo }\end{array}$ \\
\hline $\begin{array}{l}\text { McCluggage } \\
\text { WG et al } \\
\text { (2008) }\end{array}$ & NR & Two cases NR & $\begin{array}{l}\text { Foci of signet-ring cell in } \\
\text { the usual type of cervical } \\
\text { adenocarcinoma } \\
\text { Diffuse positivity to P16 }\end{array}$ & Not done & $\begin{array}{l}\text { Not } \\
\text { Done }\end{array}$ & NR & NR \\
\hline $\begin{array}{l}\text { Versas E et al } \\
(2009)\end{array}$ & $\begin{array}{l}36 \\
43\end{array}$ & $\begin{array}{l}\text { Thromboembolic events (Trousseau } \\
\text { Syndrome)Metastases of lung and } \\
\text { lymph nodes }\end{array}$ & & $\begin{array}{l}+ \text { HPV by in situ } \\
\text { hybridization }\end{array}$ & $\begin{array}{ll}- \\
-1-\end{array}$ & $\begin{array}{l}\text { Chemotherapy } \\
\text { Chemotherapy }\end{array}$ & $\begin{array}{l}\text { DOD } 7 \\
\text { wks } \\
\text { DOD } 2 \\
\text { mo }\end{array}$ \\
\hline $\begin{array}{l}\text { Balci et al } \\
(2010)\end{array}$ & 53 & Post-menopausal bleeding & $\begin{array}{l}\text { (0\% of neoplasms with SRC } \\
\text { II b3 } 55 \times 2 \text { parametrio } \mathrm{N} 1\end{array}$ & HPV type 18 & $-/$ & Surgery & NR \\
\hline
\end{tabular}

AGC-NOS: Atypical Glandular Cells not otherwise specified

AIS: adenocarcinoma in situ

DOD: dead of disease

HSIL: High-grade Squamous Intraepithelial Lesion

HPV: human papilloma virus

Mo: months NED: not evidence of disease

NR: not reported

PCR: Polymerase chain reaction amplification

Yrs: years

Wks: weeks

cervical carcinoma to the uterine corpus, although rare, may be observed [16,37-39].

As in our case, in the series of Yemelyanova et al, the cervical origin of the malignancy was demonstrated using immunohistochemical and molecular studies which respectively revealed immunoreactivity to p16 and negativity to hormone receptors plus the presence of HPV DNA in both the corpus and cervical component of the neoplasm [39].

In our case, negativity to Vimentin and positivity to CEA proved useful in excluding primary signet-ring cell carcinoma of the endometrium an entity even rarer than PCSRCC [10-12].

Positivity to p16 protein and molecular analysis using PCR revealed that this rare entity is related to HPV infection in the same way as other subtypes of primary adenocarcinoma [39-42].

\section{Conclusion}

With this report the authors have demonstrated that the spread of cervical adenocarcinoma to the uterine corpus, although rare, may be observed, and that in this instance 
immunohistochemical and molecular studies can provide sufficient information for accurate diagnosis even on small biopsy specimens.

\section{Consent}

Written informed consent was obtained from the patient for publication of this case report and any accompanying images. A copy of the written consent is available for review by the Editor-in-Chief of this journal.

\section{Abbreviations}

AGC-NOS: Atypical Glandular Cells not otherwise specified; AIS: adenocarcinoma in situ; BLAST: Basic Local Alignment Search Tool; CL: Cervical neoplastic lesion; DOD: Dead Of Disease;EL: Endometrial neoplastic lesion; End : endometrial lesion; GCDFP-15: Gross Cystic Disease Fluid Protein -15; HSIL: High-grade Squamous Intraepithelial Lesion; HPV: Human Papilloma Virus; M: molecular weight standard; Mo: months; NED: not evidence of disease; NR: not reported: PAS: Periodic acid Schiff: PaVE: Papilloma Virus Episteme; PCR: Polymerase chain reaction amplification; PSRCC: Primary Signet-Ring Cell carcinoma of the Cervix; Yrs: years; Wks: weeks,

\section{Acknowledgements}

The Authors wish to thank Professor Alex Gillan for the correction of the English language and Mrs Emilia Corradini and Mrs Gabriella Becchi for technical assistance

\section{Author details}

'Department of Pathology and Medicine of Laboratory, Section of Pathology, Parma University. ${ }^{2}$ Department of Obstetric and Gynaecologic Sciences and Neonatology, Parma University.

\section{Authors' contributions}

GG: carried out the study design and writing. SP and TD: did molecular study and participated in the literature search. RB: performed the operation of the patient. All authors read and approved the final manuscript.

\section{Competing interests}

The authors declare that they have no competing interests.

Received: 28 October 2011 Accepted: 11 January 2012

Published: 11 January 2012

\section{References}

1. el-Zimaity HM, Itani K, Graham DY: Early diagnosis of signet ring cell carcinoma of the stomac: role of the Genta stain. J Clin Pathol 1997, 50:867-8.

2. Leong FJ, Leong AS, Swift J: Signet-ring carcinoma of the prostate. Pathol Res Pract 1996, 192:1232-8, discussion 1239-41.

3. Jain V, Gupta K, Kudva R, Rodrigues GS: A case of ovarian metastasis of gallbladder carcinoma simulating primary ovarian neoplasm: diagnostic pitfalls and review of literature. Int I Gynecol Cancer 2006, 16(Suppl 1):319-21.

4. Makino T, Tsujinaka T, Mishima H, Ikenaga M, Sawamura T, Nakamori S, Fujitani K, Hirao M, Kashiwazaki M, Masuda N, Takeda M, Mano M: Primary signet-ring cell carcinoma of the colon and rectum: report of eight cases and review of 154 Japanese cases. Hepatogastroenterology 2006, 53:845-9.

5. Michal $\mathrm{M}, \mathrm{Hes} \mathrm{O}$, Kazakov DV: Primary signet-ring stromal tumor of the testis. Virchows Arch 2005, 447:107-10.

6. Chehal A, Seoud M, Taher A, Salem N, Khalil A, Shamsseddine A: Endometrial metastasis from signet-ring breast carcinoma: case report. Eur J Gynaecol Oncol 2002, 23(6):563-4.

7. Kennebeck $\mathrm{CH}$, Alagoz T: Signet ring breast carcinoma metastases limited to the endometrium and cervix. Gynecol Oncol 1998, 71:461-4.

8. Giordano G, Gnetti L, Ricci R, Merisio M, Melpignano M: Metastatic extragenital neoplasms to the uterus: A clinicopathological study of four cases. Int J Gynecol Cancer 2006, 16(Suppl 1):433-38.
9. Giordano G, Gnetti L, Pilato FP, Viviano L, Silini EM: The role of cervical smear in the diagnosis and management of extra-uterine malignancies metastatic to the cervix: Three case reports. Diagn Cytopathol 2010, 38:41-6.

10. Mooney EE, Robboy SJ, Hammond CB, Berchuck A, Bentley RC: Signet-ring cell carcinoma of the endometrium: a primary tumor masquerading as a metastasis. Int J Gynecol Pathol 1997, 16:169-72.

11. Chebib I, Chu P, Duggan MA, DiFrancesco LM: Primary signet-ring cell adenocarcinoma of the endometrium: case report and review of the literature. Int I Gynecol Pathol 2010, 29:269-72.

12. Boyd C, Cameron I, McCluggage WG: Endometrial adenocarcinoma with signet ring cells: report of two cases of an extremely rare phenomenon. Int J Gynecol Pathol 2010, 29:579-82.

13. Moll UM, Chumas JC, Mann WJ, Patsner B: Primary signet ring cell carcinoma of the uterine cervix. N Y State J Med 1990, 90:559-60.

14. Mayorga M, Garcia-Valtuille A, Fernandez F, Val-Bernal JF, Cabrera E: Adenocarcinoma of the Uterine Cervix with Massive Signet-Ring Cell differentiation. Int I Surg Pathol 1997, 5:95-100.

15. Haswani P, Arseneau J, Ferenczy A: Primary signet ring cell carcinoma of the uterine cervix: A clinicopathologic study of two cases with review of the literature. Int J Gynecol Cancer 1998, 8:374-379.

16. Cardosi RJ, Reedy MB, Van Nagell JR, Spires SE: Neuroendocrine signet ring cell adenocarcinoma of the endocervix. Int J Gynecol Cancer 1999, 9(5):433-437.

17. Moritani S, Ichihara S, Kushima R, Sugiura F, Mushika M, Silverberg SG Combined signet ring cell and glassy cell carcinoma of the uterine cervix arising in a young Japanese woman: a case report with immunohistochemical and histochemical analyses. Pathol Int 2004, 54:787-92.

18. Insabato L, Simonetti S, De Cecio R, Di Tuoro S, Bifulco G, Di Spiezio Sardo A: Primary signet-ring cell carcinoma of the uterine cervix with long term follow-up: case report. Eur J Gynaecol Oncol 2007, 28:411-4.

19. Suárez-Peñaranda JM, Abdulkader I, Barón-Duarte FJ, González Patiño E, Novo-Domínguez A, Varela-Durán J: Signet-ring cell carcinoma presenting in the uterine cervix: report of a primary and 2 metastatic cases. Int $J$ Gynecol Pathol 2007, 26:254-8.

20. McCluggage WG, Shah R, Connolly LE, McBride HA: Intestinal-type cervical adenocarcinoma in situ and adenocarcinoma exhibit a partial enteric immunophenotype with consistent expression of CDX2. Int J Gynecol Pathol 2008, 27:92-100

21. Veras E, Srodon M, Neijstrom ES, Ronnett BM: Metastatic HPV-related cervical adenocarcinomas presenting with thromboembolic events (Trousseau Syndrome): clinicopathologic characteristics of 2 cases. Int $J$ Gynecol Pathol 2009, 28(2):134-9.

22. Balci S, Saglam A: Usubutun A Primary signet-ring cell carcinoma of the cervix: Case report and review of the literature. Int I Gynecol Pathol 2010, 29:181-4.

23. de Roda Husman AM, Walboomers JM, van den Brule AJ, Meijer CJ, Snijders PJ: The use of general primers GP5 and GP6 elongated at their $3^{\prime}$ ends with adjacent highly conserved sequences improves human papillomavirus detection by PCR. J Gen Virol 1995, 76:1057-62.

24. Greer CE, Peterson SL, Kiviat NB, Manos MM: PCR amplification from paraffin-embedded tissues: effects of fixative and fixation time. Am J Clin Pathol 1991, 95:117-24

25. Kim JP, Kim SC, Yang HK: Prognostic significance of signet ring cell carcinoma of the stomach. Surg Oncol 1994, 3:221-7.

26. Gompel C, Silverberg SG: The breast malignant epithelial tumors. In Pathology in Gynecology and Obstretics. Philadelphia Lippincott 1994, 594.

27. Alguacil-Garcia A: Artifactual changes mimicking signet ring cell carcinoma in transurethral prostatectomy specimens. Am J Surg Pathol 1986, 11:795-800.

28. Arista-Nasr J, Romero-Lagarza P, Pichardo-Bahena R: Artifactual signet-ringlike cells in endoscopic biopsy of gastric lymphoma. Arch Pathol Lab Med 1997, 121:623-625.

29. McCluggage WG, Bharucha $H$, El-Agnaf $M$, Toner $P G$ : B cell signet-ring lymphoma of bone marrow. J Clin Pathol 1995, 48:275-278.

30. Dickersin GR, Young RH, Scully RE: Signet-ring stromal and related tumors of the ovary. Ultrastruct Pathol 1995, 19:401-419.

31. Kearns M, Lala PK: Life history of decidual cells. Am J Reprod Immunol 1983, 3:78-82. 
32. Ledford BE, Rankin JC, Markwald RR, Baggett B: Biochemical and morphological changes following artificially stimulated decidualization in the mouse uterus. Biol Reprod 1976, 15:529-535.

33. Monteagudo C, Merino MJ, Laporte N, Neumann RD: Value of gross cystic diseas fluid protein-15 in distinguishing metastatic breast carcinomas among poorly differentiated neoplasms involving the ovary. Hum Pathol 1991, 22:368-72.

34. Tenti P, Romagnoli S, Silini E, Zappatore R, Giunta P, Stella G, Carnevali L: Cervical adenocarcinomas express markers common to gastric, intestinal and pancreatobiliary epithelial cells. Pathol Res Pract 1994, 190:342-9.

35. Pambuccian SE, Bachowski GJ, Twiggs LB: Signet ring cell lobular carcinoma of the breast presenting in a cervicovaginal smear. A case report Acta Cytol 2000, 44:824-30.

36. Sano T, Oyama T, Kashiwabara K, Fukuda T, Nakajima : Expression status of p16 protein is associated with human papillomavirus oncogenic potential in cervical and genital lesions. Am J Pathol 1998, 153:1741-8.

37. de Jesus M, Tang W, Sadjadi M, Belmonte AH, Poon TP: Carcinoma of the cervix with extensive endometrial and myometrial involvement. Gynecol Oncol 1990, 36:263-70.

38. Gungor T, Altinkaya SO, Ozat M, Akbay S, Mollamahmutoglu L: Unusual form of superficial spreading squamous cell carcinoma of cervix involving the endometrium, bilateral tubes and ovaries: a case report with literature review. Arch Gynecol Obstet 283:323-7.

39. Yemelyanova A, Vang R, Seidman JD, Gravitt PE, Ronnett BM: Endocervica adenocarcinomas with prominent endometrial or myometrial involvement simulating primary endometrial carcinomas: utility of HPV DNA detection and immunohistochemical expression of p16 and hormone receptors to confirm the cervical origin of the corpus tumor. Am J Surg Pathol 2009, 33:914-24.

40. McCluggage WG, Jenkins D: P16 immunoreactivity may assist in the distinction between endometrial and endocervical adenocarcinoma. Int J Gynecol Pathol 2003, 22:231-35.

41. Ansari-Lari MA, Staebler A, Zaino RJ, Shah KV, Ronnett BM: Distinction of endocervical and endometrial adenocarcinomas: immunohistochemical p16 expression correlated with human papillomavirus (HPV) DNA detection. Am J Surg Pathol 2004, 28:160-7.

42. Giordano G, D'Adda T, Gnetti L, Merisio C, Gabrielli M, Melpignano M: Villoglandular adenocarcinoma of the cervix: Two new cases with morphological and molecular study. Int I Gynecol Pathol 2007, 26:199-204.

doi:10.1186/1477-7819-10-7

Cite this article as: Giordano et al: A new case of primary signet-ring cell carcinoma of the cervix with prominent endometrial and myometrial involvement: Immunohistochemical and molecular studies and review of the literature. World Journal of Surgical Oncology 2012 10:7.

\section{Submit your next manuscript to BioMed Central and take full advantage of:}

- Convenient online submission

- Thorough peer review

- No space constraints or color figure charges

- Immediate publication on acceptance

- Inclusion in PubMed, CAS, Scopus and Google Scholar

- Research which is freely available for redistribution 